\title{
Overkrysningsstudie fremfor kryssforsøk
}

\author{
Det engelske begrepet crossover study har lenge vært oversatt med kryssforsøk i Tidsskriftet. \\ Nå blir overkrysningsstudie et foretrukket alternativ.
}

Randomiserte undersøkelser er gullstandarden for å finne ut om en intervensjon er bedre enn en annen. De fleste legemiddelutprøvinger gjøres ved å sammenlikne to eller flere grupper hvor hver pasient får kun én av intervensjonene. Det vil si at gruppene følges parallelt, derav navnet parallellstudie eller parallellgruppestudie (fig 1).

Av og til kan det være hensiktsmessig å benytte en annen type design. For eksempel ved sykdom som er forholdsvis stabil og som varer over tid, kan hver pasient få først én type behandling, deretter en annen (fig 1). Hver pasient er altså sin egen kontrollperson. Det er viktig at hver behandlingsperiode er atskilt av en periode uten behandling, en såkalt utvaskingsperiode (wash-out period). På den måten sikrer man at det ikke er rester av legemidler igjen fra den første behandlingen når man går i gang med neste. Hensikten er å unngå en overføringseffekt (carry-over effect) fra den ene til neste fase i utprøvningen. På engelsk kalles denne studiedesignen for crossover study.

Hvilken design som bør brukes, avhenger av flere ting - begge har fordeler og ulemper. Parallelldesign er enklest og minst tidkrevende, mens kryssforsøk krever færre pasienter, men tar lengre tid fordi behandlingene gis etter hverandre i serie.

\section{Kryssforsøk,}

\section{kryssundersøkelse og krysstudie}

I Tidsskriftets ordliste har man siden 1980årene brukt kryssoverforsøk og kryssforsøk
(1) som avløserord for crossover study. I 1990-årene ble kryssundersøkelse og kryssforsøk brukt $(2,3)$, og slik står det fremdeles (4).

Vi registrerer nå at overkrysningsstudie brukes stadig oftere. Et søk i Tidsskriftets nettutgave for perioden 2000-11 gir 16 treff for overkrysningsstudie, fem for kryssundersøkelse, fire for kryssforsøk og tre for krysstudie (9.12. 2011).

Disse begrepene er såpass spesialiserte at de ikke står oppført i allmennordbøkene. Heller ikke i dagspressen er det stort å finne. Et søk i det elektroniske tekstarkivet Retriever, som samler avistekster fra mange år tilbake, gir kun ett treff for kryssforsøk. Det dreide seg om en studie som hadde stått i Tidsskriftet i 1989 (5). I tillegg er overkrysningsstudie registrert to ganger (i 2002 og 2010). Nettsøk gir treff på både kryssundersøkelse, kryssforsøk og krysstudie.

\section{Overkrysning er best}

Også i lærebøker og på Internett påtreffes overkrysningsstudie (6). På bokmål er det vanligst med overkrysning, ikke overkryssing (jf. krysning, krysningspunkt). På nynorsk er det overkryssing (7), på svensk överkorsning (8) og på dansk overkrydsning (9).

Begrepet overkrysning (crossover) har tradisjonelt vært brukt $i$ en helt annen sammenheng, nemlig om utveksling av gener mellom kromatider under kjønnscelledanningen. Dette fenomenet ble beskrevet på begynnelsen av 1900-tallet og tilhører den klassiske medisinske genetikk. Men det vil neppe skape forvirring å bruke betegnelsen overkrysningsstudie om en variant av randomiserte studier. Snarere tvert imot - ved å bruke en etablert oversettelse som overkrysning som likner på det engelske opphavet, vil det være lettere å få gjennomslag for oversettelsen på norsk.

\section{Anbefaling}

Bør vi skifte ut de gamle betegnelsene som begynner med kryss og i stedet ha overkrysningsstudie som foretrukket form? Vi tror at flere avløserord kan være et gode. Siden overkrysningsstudie er godt etablert i fagspråket, vil Tidsskriftet nå føye til denne formen $\mathrm{i}$ ordlisten som et foretrukket alternativ til kryssforsøk, kryssundersøkelse og krysstudie - samtidig som alle betegnelsene vil bli akseptert.

\section{Erlend Hem \\ erlend.hem@medisin.uio.no \\ Geir W. Jacobsen \\ Tidsskriftet}

Vi takker Are Brean og Petter Gjersvik for gode innspill.

\section{Erlend Hem (f. 1970) er dr.med. og assiste-} rende redaktør i Tidsskriftet.

Geir W. Jacobsen (f. 1945) er professor ved Institutt for samfunnsmedisin, Norges teknisknaturvitenskapelige universitet og medisinsk redaktør i Tidsskriftet.

\section{Parallellgruppestudie}

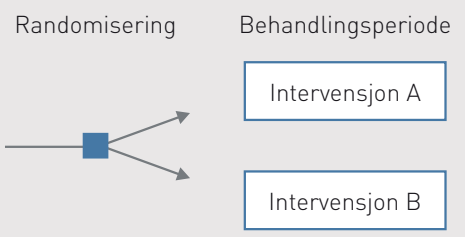

Overkrysningsstudie

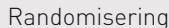

Periode 1
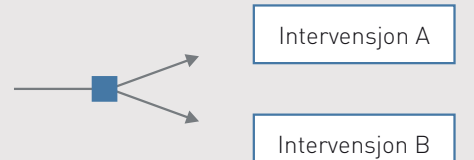

Intervensjon B
Utvaskingsperiode

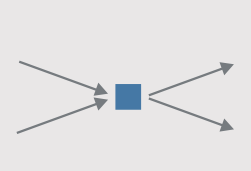

Periode 2

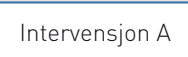

ntervensjon B

Figur 1 Parallelldesign og overkrysningsdesign

\footnotetext{
Litteratur

1. Ordliste. Utgitt av Tidsskriftets redaksjon. Oslo: Tidsskrift for Den norske legeforening, 1985: 16.

2. Skikk og bruk i Tidsskriftet: med ordliste og veiledning for manuskriptforfattere. Lysaker: Tidsskrift for Den norske legeforening, 1993: 43.

3. Skikk og bruk i Tidsskriftet. Oslo: Tidsskrift for Den norske legeforening, 1997: 41, 62.

4. Ordliste. Tidsskrift for Den norske legeforening. http://tidsskriftet.no/Innhold/

Forfatterveiledningen/Manusutforming/ Ordliste/C (9.12.2011)

5. Herpesfremgang. VG 25.3.1989: 9.

6. Laake P. Hjartåker A, Thelle DS et al, red. Epidemiologiske og kliniske forskningsmetoder. Oslo: Gyldendal Akademisk, 2007: 273, 278-9, 413-5.

7. Øyri A. Norsk medisinsk ordbok. 9. utg. Oslo: Samlaget, 2011: 802.

8. Lundh B, Malmquist J. Medicinska ord: det medicinska språket: begrepp, definitioner, termer. 3. utg. Lund: Studentlitteratur, 2001: 377.

9. Nørby S, red. Klinisk ordbog. 16. utg. København: Munksgaard, 2004: 891-2
} 